\title{
Fighting the Deadly Enterotoxemia Disease Nutritionally
}

\author{
George FW Haenlein* \\ Professor emeritus, Animal \& Food Sciences, University of Delaware, USA
}

Submission: March 20, 2018; Published: April 03, 2018

*Corresponding author: George FW Haenlein, Professor emeritus, Animal \& Food Sciences, University of Delaware, USA, Email: ghaenlein@gmail.com

\begin{abstract}
Ruminants, such as goats and cows are designed by nature to live on roughage, i.e. fibrous feeds and are great converters of such feeds that are not very digestible nor nutritious, into meat, milk and wool fiber. Actually it is a symbiotic relationship of the ruminant with a multitude of beneficial bacterial populations, which do digest the fiber and while the ruminant animal plays their host, it also benefits from their digestion products. There is one condition, these beneficial bacteria have a $\mathrm{pH}$ optimum to live, and when this $\mathrm{pH}$ is disturbed other bacteria take over, which however have toxic effects on the ruminant animal and make it deadly sick with a condition called Entertoxemia. From practical experience it is discussed that when the disturbance of the rumen environment is recognized and reversed by providing fiber with an appetizing feed, the sunflower seed, the disease can be cured, when managing promptly, without the need to use otherwise effective vaccinations against the offending Clostridia bacteria.
\end{abstract}

Keywords : Ruminant pH; Rumen bacteria; Fibrous feeds; Clostridium perfringens; Enterotoxemia

\section{Introduction}

Enterotoxemia is a deadly disease common in modern dairy goat husbandry and dairy cow husbandry. Actually it is a man-made disease, because it occurs only in modern high milk productivity herds. It is also known as overeating disease, because in traditional dairy goat or dairy cow management of letting the herd graze, milk production is the sole result of eating the fibrous range or pasture forage. Under intensive management the does or cows are fed extra grain rations to sustain high milk production. This grain ration has high starch content usually and is highly digestible. When given an opportunity goat kids and adults like to engorge on a grain ration, because it is usually very palatable. Then the rapid fermentation of starch in the rumen changes the usual bacterial environment [1] and causes the $\mathrm{pH}$ of the rumen contents to drop on the acid side to a condition called acidosis, which is toxic. However, it allows Clostridia perfringens bacteria to grow and cause the goat or cow to be feeling very sick, which can proceed to convulsions, coma and death very shortly. So called "sudden death" of kids maybe the first indication of the presence of this serious disease. Therefore many goat owners believe in precaution as their best weapon in their fight against this deadly disease using vaccination with bacterin toxoid type $\mathrm{C}$ and D usually at least twice annually.

\section{Practical Experience with Goats}

In my experience of owning and managing a registered Saanen dairy goat herd of 25 milking head with high production for 20 years. I have never vaccinated my goats and have never had a single case of enterotoxemia. Since the predisposition to this disease is the occurrence of eating too much of a highly digestible grain ration, it seemed logical that prevention should focus on changing the feeding management including making sure of secure fencing in height and on the bottom, so that the goats could not accidentally break out from their pens and invade the feed storage room, where sacks of commercial grain rations and feed supplements would be stored. High producing dairy goats need a supplementary grain ration in order to maintain the high level of milk production. Thus there are two ways to make sure that the goats do not overeat the grain ration. One is to prevent goats from escaping and discovering it. The other is to establish a feeding schedule, which provides the goats with the needed long fiber, which is missing in the grain ration, by offering frequently attractively smelling grass and alfalfa or clover hay. Usually commercial grain or home-mixed grain rations do not contain long fiber, which is the reason for the grain to ferment rapidly and become a favored medium for the Clostridia bacteria but which are toxic for the goat.

\section{Feeding Hay}

Thus the nutritional way of fighting Enterotoxemia is to provide fiber in the ration, like hay and not finely ground fiber. Commercial processing of grain rations always is preceded by finely grinding the ingredients, even hay, if it is included. Some 40 years ago extensive research at the USDA 
Agricultural Experiment Station in Beltsville - Maryland and at the University of Delaware focused on the development of the necessary machinery for mobile "pelleted" or "wafered" hay $[2,3]$ during harvest in the field and about the nutritional qualities of such densely packaged hay. Pelleting is a common commercial practice for packaging bulky ground grain, but their sizes are usually less than $1 / 2$ inch in diameter. When the hay pellets had however a diameter of at least $1 \mathrm{inch}$, they provided for dairy cattle and dairy goats the need of chewing the lengthy fiber to prevent acidosis and enterotoxemia. It was discovered that the minimum of $17 \%$ fiber content in the daily ration was not enough, but the fiber had to have a minimum length of 1 inch to prevent acidosis [4], which would be occurring in cows just as in goats otherwise. The practice of feeding pelleted hay of this large 1 inch diameter size became popular in Europe under the name "cobs", while here in USA chopping hay and feeding it in "complete" rations mixed with the other grain, especially for dairy cows has been more economical and equally effective in preventing acidosis. Goats are fastidious and often very wasteful as they are searching for the good part when hay is fed, thus another feed for providing fiber is needed to be more effective, and that is the sunflower seed.

\section{Feeding Sunflower Seeds}

Nature has provided us in the form of the sunflower seed with an ideal combination of highly nutritious content in a high fiber wrapper, generally in two varieties, "striped" and "black", the difference being more fat content in the black seed but more overall content in the striped seed. The seeds are very palatable equal to a grain ration and attract goats. However the high fiber content of the striped sunflower seed, $31 \%$ compared to oats $12 \%$ and shelled corn $2 \%$, is ideally suited to prevent rumen acidosis no matter how much the goats eat from it [5]. Sunflower seeds also contain $28 \%$ fat and $18 \%$ protein, compared to $6 \%$ and $14 \%$ for oats, and $4 \%$ and $11 \%$ for corn, respectively. Thus sunflower seeds can function very well as a "complete" grain ration substitute with the added benefit of sufficient fiber to prevent acidosis and Enterotoxemia. In my experience sunflower seeds can replace totally or partially a commercial grain ration, still maintain high milk production and not have the risk of Enterotoxemia. In my experience 1 to 3 pounds of sunflower seeds per day are usually sufficient for fresh goats to maintain high milk production [6]. In some research at South Dakota State University dairy cow rations were substituted with $10 \%$ sunflower seeds and their milk production increased by $13 \%$ [6]. Sunflower seeds also have higher mineral contents ( $\mathrm{Ca}, \mathrm{P}, \mathrm{K}, \mathrm{Fe}$ and $\mathrm{Mn}$ ) than oats or corn and their metabolizable and net energy contents are in between oats and corn. In my experience goats that are fresh or are in poor body condition or which have loose bowls receive preferably extra sunflower seeds. Goats have normally pelleted feces or bowls and when goats have loose bowls like normal cow manure, this is an indication that they do not receive enough fiber in their daily ration.

\section{Economics}

The price of sunflower seeds is generally higher than that of a commercial grain ration for goats, mainly because they are popular for winter wild bird feeding. By the end of winter there might be some opportunity to buy excess storage bags of sunflower seeds, preferably of the striped variety. However, in calculating the economics of feeding sunflower seeds, one needs to include the cost of veterinary service and vaccinations for calculating the total cost of prevention of Enterotoxemia, and then the cost of sunflower seeds is not too high.

\section{References}

1. Haenlein GFW, Baumgardt B (1967) Morphological and physiological changes of the calfstomach during early weaning. Z Tierphysiol Tierern Futtermittelk 21: 327-333.

2. Haenlein GFW, Burton DW, Hoyt HC, Mitchell WH, Richards CR (1962) Effects of expanding or pelleting upon feed digestibility and heifer growth. J Dairy Sci 45(6): 754-758.

3. Haenlein GFW, Holdren RD (1965) Response of sheep to wafered alfalfa hay having different physical characteristics. J Animal Sci 24(3): 810-818.

4. Haenlein GFW (1980) Influence of grinding and pelleting upon the digestibility of alfalfa hay. Z Wirtschaftseig Futter 26: 140-149.

5. Haenlein GFW (1982) Feeding sunflowers can prevent enterotoxemia. Feedstuffs 23(2).

6. Luttmann G (1988) Sunflower seeds and enterotoxemia. Dairy Goat Journal 66(3): 37 . 
This work is licensed under Creative Commons Attribution 4.0 License DOI: 10.19080/NFSIJ.2018.06.555681
Your next submission with Juniper Publishers will reach you the below assets

- Quality Editorial service

- Swift Peer Review

- Reprints availability

- E-prints Service

- Manuscript Podcast for convenient understanding

- Global attainment for your research

- Manuscript accessibility in different formats

( Pdf, E-pub, Full Text, Audio)

- Unceasing customer service

Track the below URL for one-step submission https://juniperpublishers.com/online-submission.php 